\title{
Organizational public value and employee life satisfaction: the mediating roles of work engagement and organizational citizenship behavior
}

\section{Timo Meynhardt, Steven A. Brieger \& Carolin Hermann}

To cite this article: Timo Meynhardt, Steven A. Brieger \& Carolin Hermann (2018): Organizational public value and employee life satisfaction: the mediating roles of work engagement and organizational citizenship behavior, The International Journal of Human Resource Management

To link to this article: https://doi.org/10.1080/09585192.2017.1416653

曲 Published online: 16 Jan 2018.

Submit your article to this journal $₫$

Q View related articles $\square$

View Crossmark data ¿ 


\title{
Organizational public value and employee life satisfaction: the mediating roles of work engagement and organizational citizenship behavior
}

\author{
Timo Meynhardt ${ }^{\mathrm{a}, \mathrm{b}}$, Steven A. Brieger ${ }^{\mathrm{b}, \mathrm{c}}$ and Carolin Hermann ${ }^{\mathrm{b}}$ \\ aDr. Arend Oetker Chair of Business Psychology and Leadership, HHL Leipzig Graduate School of \\ Management, Leipzig, Germany; ${ }^{b}$ Center for Leadership and Values in Society, University of St. Gallen, \\ St. Gallen, Switzerland; Institute of Management \& Organization, Leuphana University of Lüneburg, \\ Lüneburg, Germany
}

\begin{abstract}
Building on Meynhardt's public value concept, which has been developed to make transparent an organization's contributions to the common good, we investigate the influence of organizational common good practices in the perceptions of employees (measured as public value) on employees' work attitudes and life satisfaction. The proposed model is tested on a sample of 1045 Swiss employees taken from the 2015 Swiss Public Value Atlas data-set. Study findings reveal that organizational public value is positively related to employee life satisfaction, and that this relationship is partially mediated by work engagement and organizational citizenship behavior. Further, we show that employee common good orientations strengthen the positive impact of organizational public value on employee work engagement and organizational citizenship behavior. Results also provide evidence that the indirect effects of organizational public value on employee life satisfaction via work engagement and organizational citizenship behavior are stronger at higher employee common good orientation levels.
\end{abstract}

\section{KEYWORDS}

Public value; life satisfaction; work engagement; organizational citizenship behavior; CSR; common good; social performance

\section{Introduction}

Organizations' common good practices, which consider the production of goods and services to satisfy society's needs and wants, have become increasingly important among scholars and practitioners (Argandoña, 1998; Brammer, Millington, \& Rayton, 2007; Carcello, 2009; Melé, 2009; Meynhardt \& Diefenbach, 2012; Meynhardt \& Gomez, 2016; Sison \& Fontrodona, 2013). Private and public organizations often pursue efforts to increase public welfare (e.g. CSR strategies, multi-stakeholder dialogue, public value management, sustainability reporting) 
not only to establish and secure legitimacy, but also to increase economic success (Müller \& Brieger, 2016; Porter \& Kramer, 2011; Schaltegger \& Hörisch, 2015). Several studies have emphasized the positive effects of common good practices for owners and external stakeholders, such as customers, investors, and governments (Bhattacharya \& Sen, 2004; Ghobadian, Money, \& Hillenbrand, 2015; Orlitzky \& Benjamin, 2001).

However, while the impacts of organizational common good practices on owners and external stakeholders have been thoroughly researched, knowledge is limited concerning these practices' influence on employee outcomes such as satisfaction, reduction in turnover intentions, or organizational trust, and their underlying mechanisms (van den Broeck, Vansteenkiste, Witte, \& Lens, 2008; Du, Bhattacharya, \& Sen, 2015; Glavas \& Kelley, 2014; Roeck, Marique, Stinglhamber, \& Swaen, 2014). This dearth can be attributed in part to the general lack of individual-level research, including a low number of mediation and moderation analysis studies (Aguinis \& Glavas, 2012; Glavas \& Kelley, 2014). The limited insights seem surprising, since as an organization's most important resource, employees are its representing organ. Employees are the stakeholder group that is most integrated into and identified with the employing organization, and they are largely responsible for an organization's innovativeness and financial success. Thus, a better understanding what conditions make employees more enthusiastic, more motivated, and more proactive at work would be an important step forward.

Building on Meynhardt's psychology-based public value concept (Meynhardt, 2009, 2015), which has been developed to make transparent an organization's contributions to the common good, we address this research gap. The basic idea is that human beings feel positive about something that results in a direct personal gain and/or a positive impact on the community or society they live in. The latter results in public value and points to an organization's contributions to both social stability and progress, which in turn enable individuals to develop and grow.

In this paper we examine, first, employees' perception of what impacts organizational common good practices (measured as public value) have on employee life satisfaction. Second, we investigate whether work engagement and organizational citizenship behavior play mediating roles in the relationship between organizational public value and employee life satisfaction. Further, we examine whether employees' common good orientations moderate the relationship between an organization's public value and both mediators, and whether the indirect effect of organizational public value on employee life satisfaction via each mediator differs across high and low employee common good orientation levels.

We empirically test our model (Figure 1) by analyzing 1045 employees of Swiss private and public organizations and non-governmental organizations. We took data from the Swiss Public Value Atlas data-set (Public Value Atlas Switzerland, 2015), which is built on Meynhardt's public value concept and was conceptualized to make organizations' contributions to the common good publicly transparent. 


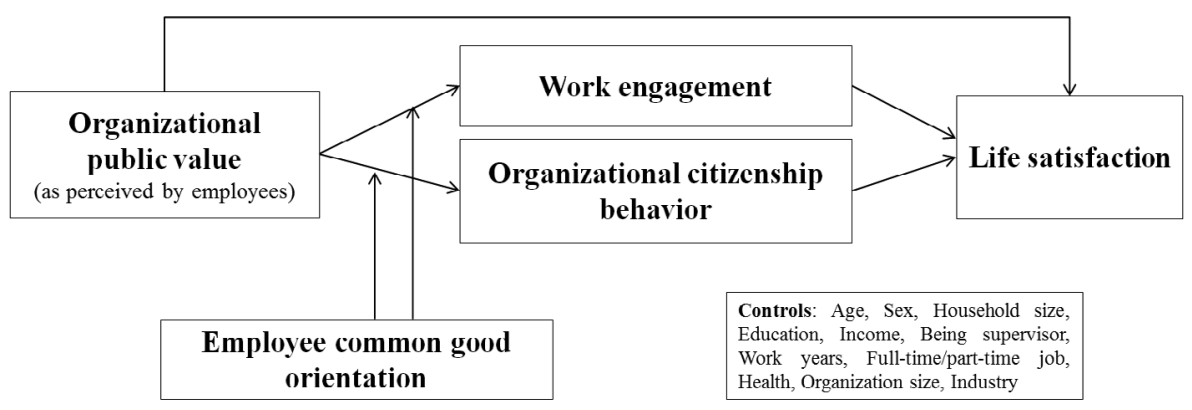

Figure 1. Model.

Our paper has the following structure. First, we introduce the public value concept, which is the basis of our data-set and our independent variable. Next, we present our model and develop the hypotheses. We then discuss the methodology in terms of sampling, data collection, and measures. That discussion is followed by a description of our analysis and the main findings. The last sections provide a discussion of our results and conclusions.

\section{Theoretical background and hypotheses}

\section{Defining public value}

As previous studies have shown, organizational contributions to the common good can be detected by means of various concepts, such as sustainability, public value, or corporate citizenship (Brammer et al., 2007; Meynhardt \& Gomez, 2016; Schwartz \& Carroll, 2008). In this study, we use the more recent common good approach in the business ethics debate - the public value concept (Meynhardt, 2009, 2015; Meynhardt \& Gomez, 2016). Public value creation means sustaining or increasing individuals' chances of favorable experiences of community and society, which helps them to develop and grow. Public value is a value creation toward the common good, which serves as an enabling function for the individual. Meynhardt's psychology-based public value concept seeks to make transparent organizational contributions to the common good and their managerial consequences, arguing that organizations can only create value for individuals and for society if they respond positively to individuals' basic needs. Basic needs form the basis of individual evaluations and serve as subjective reference points as to whether a fit occurs between one's needs and perceived reality. Public value creation is thus 'situated in relationships between the individual and society, founded in individuals, constituted by subjective evaluations against basic needs, activated by and realized in emotional-motivational states, and produced and reproduced in experience-intense practices' (Meynhardt, 2009, p. 212).

Evaluation is a valuation process, since people implicitly assess value against the fulfillment of their needs. Meynhardt's public value concept draws on 
cognitive-experiential self-theory (Epstein, 2003), which holds that people have four equally important basic needs: (1) to have a positive self-evaluation, (2) to maximize pleasure and avoid pain, (3) to gain control and coherence over their conceptual system, and (4) to have positive relationships (Figure 2). In this view, these needs are essential: they relate to fundamental structures of personality and are functionally extremely relevant, and invalidating them would destabilize the 'entire conceptual system' (Epstein, 1993, p. 322).

'Which function, if any, is dominant varies among individuals and within individuals over time' (Epstein, 1989, p. 8). The basic need dimensions also show the importance of social collectives in people's lives, since these mediate or moderate experience. Individuals evaluate organizations on the basis of not only what these entities do for them, but also what they do for the public in general, which in turn is also resource for individual attitudes and values. Thus, individuals evaluate organizational behavior for their own interests, but also as a representative of a public. Via this very self-referential mechanism, individuals are assumed to create meaning and make sense of their environments and by doing so relate to a social collective (e.g. community and society). Following Meynhardt's notion, public value is a necessary fiction following an as if logic of constructing worldviews, and the personal imagination of the public dimension is a prerequisite for individual development and identity.

Thus, public value represents what individuals value against the background of their own and the public's interests. In other words, public value is value for the public as a result of individuals' evaluations about how their basic human needs

\begin{tabular}{|c|c|c|}
\hline Basic need... & Translation into a motivation for... (examples) & $\begin{array}{l}\text { Basic value } \\
\text { dimension }\end{array}$ \\
\hline $\begin{array}{l}\text { for positive self- } \\
\text { evaluation }\end{array}$ & $\begin{array}{l}\text { - positive self-concept and self-worth } \\
\text { - consistent relationship between self and } \\
\text { environment } \\
\text { - feeling of high self-esteem (in social } \\
\text { comparison) }\end{array}$ & Moral-ethical \\
\hline $\begin{array}{l}\text { to maximize } \\
\text { pleasure and } \\
\text { avoid pain }\end{array}$ & $\begin{array}{l}\text { - positive emotions and avoidance of negative } \\
\text { feelings } \\
\text { - flow experience } \\
\text { — experience of self-efficacy due to action }\end{array}$ & Hedonistic-aesthetical \\
\hline $\begin{array}{l}\text { to gain control } \\
\text { and coherence } \\
\text { over one's } \\
\text { conceptual } \\
\text { system }\end{array}$ & $\begin{array}{l}\text { - understanding and controlling one's } \\
\text { environment } \\
\text { - predictability of cause-and-effect relationships } \\
\text { - ability to control expectations to cause desired } \\
\text { outcomes }\end{array}$ & $\begin{array}{l}\text { Utilitarian- } \\
\text { instrumental }\end{array}$ \\
\hline $\begin{array}{l}\text { for positive } \\
\text { relationships }\end{array}$ & $\begin{array}{l}\text { - relatedness and belongingness } \\
\text { — attachment and group identity } \\
\text { — optimal balance between intimacy and distance }\end{array}$ & Political-social \\
\hline
\end{tabular}

Figure 2. Relationship between basic needs and basic value dimensions (Meynhardt, 2009, p. 203) 
are influenced in relationships involving the public. If an individual's needs are fulfilled, his or her evaluation is positive; otherwise, it might be negative. Public value then is also

value from the public, i.e. "drawn" from the experience of the public. The public is an indispensable operational fiction of society. Any impact on shared experience about the quality of the relationship between the individual and society can be described as public value creation. (Meynhardt, 2009, p. 212)

The psychological mechanism of linking individual experience with a social collective follows the line of thinking as conceptualized in symbolic interactionism (Mead, 1934/1962). It argues that human beings develop a sense of selfhood and personal identity by relating cognitively to a larger social environment, for example by envisioning what is expected in certain roles and by generalizing individual perceptions. By integrating isolated streams of experience into a 'generalized other', people form a gestalt (in our case a social collective) that serves as a resource for a sense of belonging and individual development (Meynhardt \& Bartholomes, 2011).

Against this foundational background of a mechanism linking individuals with social collectives, Meynhardt $(2009,2015)$ translates four basic need dimensions from cognitive-experiential self-theory into four public value dimensions for organizational research:

(1) Morality - the basic need for positive self-evaluation:

This basic need focuses on a person's self-concept and self-worth and corresponds to a moral-ethical value dimension. From a societal perspective, an action is evaluated concerning whether or not it leads to equality within a social group and matches the collectively shared understanding of human dignity and justice. This process always depends on one's self-concept and self-worth. An organization creates public value along this value dimension if it behaves decently and allows an individual to retain a positive sense of self-worth. However, if the organization does not respect accepted moral-ethical standards, individuals may feel that public value is being destroyed.

(2) Quality of life - the basic need to maximize pleasure and avoid pain:

People have a basic need to avoid pain and increase pleasure. From this perspective, an organization creates value when an individual evaluates an organization's actions as contributing to positive experiences at a collective level, thereby increasing the individual's quality of life.

(3) Task fulfillment - the basic need to gain control and coherence over one's conceptual system:

People want to find orientation in the environment that surrounds them, to better understand how things relate to one another and to discern the underlying mechanisms to be able to influence them. Transferred to the organizational context, people experience this need for control and orientation as satisfied when 
they see the use of services and products and evaluate an organization's actions as being purposeful for society.

(4) Social cohesion - the basic need for positive relationships:

Social cohesion and approval are crucial for an individual to develop a sense of belonging and identity. Organizations can be evaluated from a political-social perspective concerning their contributions to fostering a feeling and sense of social cohesion within a social group. Acknowledging a political-social value depends on collectively shared values, which relate to social relationships.

Empirical support for the outlined structure was found in a study with Germany’s Federal Labor Agency (Meynhardt \& Bartholomes, 2011).

\section{Public value's influence on employee life satisfaction}

Our model seeks to create understanding about the relationship between employee perceptions of organizational public value and employee life satisfaction and their underlying mechanisms. Research has revealed that psychological need satisfaction is a predictor of life satisfaction (Greguras \& Diefendorff, 2010). Thus, we argue that the more effectively an organization responds to its employees' basic needs, the stronger its impacts on employee life satisfaction.

We propose a positive relationship between an organization's public value and employee life satisfaction, which can be explained by employees' primary interest in working for an organization that can fulfill basic human needs. If an organization responds to these basic needs, its employees should evaluate their work as more significant, rewarding, and worthwhile for themselves and others (May, Gilson, \& Harter, 2004). Thus, a lack of meaning in work can lead to alienation from that work.

Research has widely recognized the importance of meaningfulness in work with respect to employees' intrinsic motivation, productivity, and satisfaction (Fried \& Ferris, 1987; Hackman \& Oldham, 1980; Michaelson, Pratt, Grant, \& Dunn, 2014; Rosso, Dekas, \& Wrzesniewski, 2010; Woods \& Sofat, 2013). We argue that public value is a resource for employees (Meynhardt, 2015). Since public value responds to basic human needs, it should empower employees. Public value also provides employees with the rationale that work requires awareness of its value for themselves, significant others, and the wider public. In sum, an organization's public value should positively affect employee satisfaction.

A further explanation of the link between organizational public value and employee life satisfaction can be found in social identity theory (Ashfort \& Mael, 1989; He \& Brown, 2013; Stryker \& Burke, 2000). According to social identity theory, individuals tend to identify with the organization they work for and view themselves as members. Accordingly, membership in the employing organization influences employees' self-concepts. Individuals try to establish or enhance their positive self-concept by comparing their own characteristics to those of individuals 
and groups they belong to (Brammer et al., 2007). Social identity theory proposes that people tend to identify with organizations that are highly prestigious and have strong reputations (Ashfort \& Mael, 1989). Thus, employees are more satisfied if they work for an employing organization with an attractive image. When an organization contributes to the common good through socially responsible behaviors, its employees gain more recognition in society. Employees who work for organizations that pay attention to the common good might profit from more positive acknowledgment from significant others, which enhances their positive self-concept and makes them feel more satisfied in their lives (Vlachos, Panagopoulos, \& Rapp, 2013).

A few studies have investigated the effects of socially responsible company behaviors concerning job satisfaction and life satisfaction. For instance, a meta-analysis, demonstrated that job satisfaction and perceived justice are positively related (Colquitt, Conlon, Wesson, Porter, \& Ng, 2001). A later study found evidence that corporate ethics programs and social responsibility positively affect employee job satisfaction (Valentine \& Fleischman, 2008). Similar results have been discovered for life satisfaction, as a study revealed a positive link between corporate ethical behavior intentions and life satisfaction (Sardžoska \& Tang, 2009). Other work has shown a positive effect of ethical leadership on employee job satisfaction and life satisfaction (Yang, 2014).

Job satisfaction and life satisfaction are linked and reciprocally connected (Judge \& Watanabe, 1993; Tait, Padgett, \& Baldwin, 1989). However, a review study found that research into life satisfaction is under-represented in management (Erdogan, Bauer, Truxillo, \& Mansfield, 2012). Far more studies in the management discipline have been conducted into job satisfaction than into life satisfaction (Erdogan et al., 2012). This imbalance is surprising, since life satisfaction has been shown to be a better predictor of job performance than job satisfaction (Wright \& Cropanzano, 2000). Also, life satisfaction allows a much more comprehensive view of an individual that is not limited to work life (Erdogan et al., 2012). Thus, we focus on how perceptions of organizational public value influence life satisfaction rather than job satisfaction:

Hypothesis 1: Organizational public value will be positively related to employee life satisfaction.

\section{The mediating role of work engagement}

We suggest that the positive relationship between public value and life satisfaction can be partially explained through increased levels of work engagement. Work engagement has been conceptualized in many ways, resulting in several definitions, theories, and measurement instruments, as well as indecisiveness about the construct's name (Saks \& Gruman, 2014; Schaufeli \& Bakker, 2010). The earliest concept of engagement emphasizes work roles and characterizes personal engagement as 'the harnessing of organization members' selves to their work roles; in 
engagement, people employ and express themselves physically, cognitively, and emotionally during role performances' (Kahn, 1990, p. 694).

More recently, two primary perspectives on engagement have emerged (Bakker, Schaufeli, Leiter, \& Taris, 2008; Hakanen \& Schaufeli, 2012). One view is that work engagement is the opposite of burnout (Leiter, Bakker, \& Maslach, 2014; Maslach, Schaufeli, \& Leiter, 2001). In this view, engagement consists of energy, involvement, and efficacy, which are direct antipodes of the three burnout dimensions of exhaustion, cynicism, and reduced professional efficacy (Maslach et al., 2001). Thus, engagement could be measured by the opposite scores of the Maslach Burnout Inventory (Maslach \& Jackson, 1981).

However, the possibility of this complementary conceptualization has been questioned, because low burnout levels may not translate into high work engagement levels, or vice versa (Schaufeli \& Salanova, 2011). Thus, another primary perspective considers work engagement as an independent concept and as the positive counterpart of burnout but measured differently (Schaufeli, Salanova, GonzálezRomá, \& Bakker, 2002). Work engagement is 'a positive, fulfilling, work-related state of mind that is characterized by vigor, dedication, and absorption' (Schaufeli et al., 2002, p. 74). Studies have confirmed that burnout and engagement are negatively related and should be measured independently (Hakanen \& Schaufeli, 2012; Schaufeli \& Bakker, 2004a). We adapt the concept of work engagement proposed by Schaufeli and colleagues and argue that a high public value positively influences work engagement.

To date, management and psychology research has paid no attention to the question of how an organization's contributions to the common good shape employee work engagement. However, we know that organizational socially responsible behavior, such as organizational ethics, corporate ethical values, and CSR initiatives, directly influences employee commitment to an organization, employee organizational identification, and employee attraction and retention (Brammer, He, \& Mellahi, 2015; Brammer et al., 2007; Farooq, Payaud, Merunka, \& Valette-Florence, 2014; Glavas \& Godwin, 2013; Kim, Lee, Lee, \& Kim, 2010; Mory, Wirtz, \& Göttel, 2015). For instance, CSR initiatives positively affect employee creativity, given an adequate level of corporate ability in producing products and services (Brammer et al., 2015). In addition, employee participation in CSR activities positively relates to identification with a company, and company CSR initiatives increase employee identification with a company through perceived external prestige (Kim et al., 2010). Further, the relationship between CSR and affective organizational commitment is fully mediated by organizational trust and organizational identification (Farooq et al., 2014). The positive impacts of organizational socially responsible behavior on employee work attitudes and behaviors are often explained via social identity theory, which we have introduced above. If employees strongly identify with their employing organizations, which create public value, they will probably show a higher work engagement level, for instance by being more enthusiastic about and energetic at work. 
Increased work engagement levels may in turn positively affect life satisfaction and thereby partially explain the positive relationship between public value and life satisfaction. Research has shown that employees who are more engaged in their work have higher satisfaction levels (Bakker et al., 2008; Caesens, Stinglhamber, \& Luypaert, 2014; Grawitch \& Barber, 2010; Hakanen \& Schaufeli, 2012). Positive feelings associated with work engagement may have spillover effects on general well-being, which affect life satisfaction (Hakanen \& Schaufeli, 2012) and can be explained by conservation of resources theory, which posits that resources lead to gaining further resources and increasing well-being (Hobfoll, 2001).

On the basis of these insights, we suggest that work engagement plays a mediating role in the relationship between public value and life satisfaction. We propose that a higher public value of the employing organization in the perceptions of employees will positively relate to their work engagement, which in turn will lead to higher life satisfaction. We hypothesize:

Hypothesis 2a: Organizational public value will be positively linked to work engagement.

Hypothesis 2b: Work engagement will partially mediate the relationship between organizational public value and employee life satisfaction.

\section{The mediating role of organizational citizenship behavior}

Further, we argue that organizational citizenship behavior is a second mediator in the relationship between organizational public value and life satisfaction. Organizational citizenship behavior has been described as individual behavior that is discretionary, not directly or explicitly recognized by the formal reward system, and that in aggregate promotes the effective functioning of the organization' (Organ, 1988, p. 4). Organizational citizenship behavior can include several categories, such as helpfulness, generalized compliance, own initiative, conscientiousness, or civic virtue (Foote \& Li-Ping Tang, 2008; Podsakoff, MacKenzie, Paine, \& Bachrach, 2000).

The relationship between organizational common good initiatives and organizational citizenship behavior in general has received little attention in the business ethics debate (Lin, Lyau, Tsai, Chen, \& Chin, 2010). However, four empirical studies found evidence for a positive relationship between organizational common good practices and individual citizenship behavior for an organization (Choi \& Yu, 2014; Hansen, Dunford, Boss, Boss, \& Angermeier, 2011; Lin et al., 2010; Newman, Nielsen, \& Miao, 2015). Recently, researchers have shown that CSR positively affects employee creativity, an element of civic virtue (Brammer et al., 2015).

On the basis of these findings and the idea that public value is a resource for employees to become more motivated to get involved at work, we propose a positive link between an organization's public value and employee organizational citizenship behaviors. In accordance with social identity theory, public value should increase employees' identification with their organizations owing to better organizational reputations. Besides organizational identification, the 
organizational citizenship behavior level should also be affected if employees wish to give something back to the organizations they work for. An organization's fulfillment of employees' basic needs by contributing to social cohesion and quality of life in society and offering employees an inspirational, stimulating, and supportive work environment should positively affect employees' willingness to improve their work skills, motivation, general initiative, and proactive behavior.

Strong identification can be an important antecedent of motivation to invest in an organization. This assumption is strongly linked with argument patterns of social exchange theory, which emphasizes reciprocity in individuals' behaviors (Blau, 2008; Collier \& Esteban, 2007; Farooq et al., 2014). Individuals engage in interactions with others to increase their own benefits and achieve their own goals. Because individuals have different stocks of resources, collaboration is mutually beneficial. Accordingly, employees are more likely to respond to positive treatment from an organization that contributes significantly to the common good (Gond, Igalens, Swaen, \& El Akremi, 2011).

Increased levels of organizational citizenship behavior through belonging to an organization with a high public value contribution should cause satisfaction levels of employees to rise. In fact, some studies have confirmed a positive link between organizational citizenship behavior and satisfaction (Dávila \& Finkelstein, 2013; Lambert, 2010). For instance, a positive relationship exists between organizational citizenship behavior and life satisfaction (Lambert, 2010), as employees who engage in organizational citizenship behavior have a positive experience toward themselves and their work, which creates a spillover effect onto overall life satisfaction. Thus, organizational citizenship behavior is likely to be one of the mechanisms that could explain the positive link between public value and life satisfaction. On the basis of these results, we propose a mediating effect of organizational citizenship behavior concerning the relationship between an organization's public value and employee life satisfaction. We hypothesize:

Hypothesis $3 a$ : Organizational public value will be positively linked to organizational citizenship behavior.

Hypothesis $3 b$ : Organizational citizenship behavior will partially mediate the relationship between organizational public value and employee life satisfaction.

\section{The moderating role of employee common good orientation}

We next discuss whether employee common good orientation could moderate the relationships between an organization's public value and the mediators. Employee common good orientation refers to employees' ideological job needs and is linked to employees' demands for organizational common good practices. Like consumers or owners, employees vary in their support for the common good, which is attributed to the spheres of knowledge and values. To form a vision of the common good, each individual needs knowledge of what is important and appreciated in society. Knowledge gives human beings the capacity to carefully review and 
reconsider behaviors and attitudes. Knowledge also makes it possible to ignore narrow self-interest views and to broaden one's perspectives, including human flourishing and the interests of all people in a community or society (Welzel, 2013). Only by gaining deeper insights into the functioning of society are people able to create a vision of a common good that is in the interest of the individual and the public.

Concerning the question what constitutes the common good, the sphere of knowledge is also directly linked to the sphere of values; they are mutually dependent (Welzel, 2013). Values are 'desirable, transsituational goals, varying in importance, that serve as guiding principles in people's lives' (Schwartz \& Bardi, 2001, p. 269). Values are commonly specified as individual endorsements that reflect what is 'good or bad, important or unimportant, desirable or undesirable' in life (West, Hillenbrand, \& Money, 2015). Research has shown that personal values influence attitudes toward business ethics issues (Collins, Steg, \& Koning, 2007; Giacalone, Jurkiewicz, \& Deckop, 2008). While altruistic values are often positively linked to favorable attitudes toward responsible and sustainable business practices, negative relationships have been found for egoistic values (Fritzsche \& Oz, 2007; Shafer, Fukukawa, \& Lee, 2007; Simmons, Shafer, \& Snell, 2013). Further, there is also evidence that cultural values are important for people's perceptions of an organization's contributions to the common good. Kim and Kim (2010) point out that individualism and power distance relate negatively to corporate responsibility orientation, while collectivism, high uncertainty, and long-term orientation relate positively to corporate responsibility orientation. $\mathrm{Ng}$ and Burke (2010) found a positive relationship between collectivism and positive sustainability attitudes. In contrast, Inglehart $(1995,1997)$ and Franzen (2003) showed empirical evidence that people express a higher environmental orientation in countries in which postmaterialist values are more prevalent.

We suggest that this combination of knowledge and values that culminate in employee common good orientation moderates the relationship between an organization's public value and the aforementioned mediators. If an employee shows concern for the common good, it can be expected that he or she will show more positive outcomes concerning work engagement and organizational citizenship behavior when the employing organization contributes more to the common good. In turn, the employee's life satisfaction should be positively affected. The mechanism that underlies this link can be explained by social identity theory, as described above. Employees who are more sensitive to common good issues should show stronger identification with an employing organization that has high public value creation. Thus, we hypothesize:

Hypothesis 4a: The positive relationship between organizational public value and work engagement will be moderated by employee common good orientation such that the relationship will be stronger when employee common good orientation is high.

Hypothesis 4b: The positive relationship between organizational public value and organizational citizenship behavior will be moderated by employee common good 
orientation such that the relationship will be stronger when employee common good orientation is high.

Employee common good orientation is also likely to moderate the strength of the mediators for the relationship between public value and self-reported life satisfaction. As we predict a stronger relationship between public value and the mediators when employee common good orientation is stronger, the positive and indirect effect of public value on life satisfaction via each mediator should be stronger if the employee has a higher common good orientation. Following social identity theory, congruence between values and attributes intensifies solidarity between an employee and the employing organization. Value congruence occurs when employees' values correspond to their perceptions of the organization's values (Edwards \& Cable, 2009). Value congruence influences levels of identification, satisfaction, cohesion, and commitment (Boxx, Randall, \& Dunn, 1991; Siegall $\&$ McDonald, 2004). If an employee's common good orientation matches the employing organization's perceived public value, value congruence is high and should alter public value's indirect influence on employee satisfaction. Thus, if an employee has a higher common good orientation level, the moderation effect of employee common good orientation on life satisfaction through the mediators should be strongest. Thus:

Hypothesis 5a: The public value's indirect effect on life satisfaction via work engagement should be stronger if the employee common good orientation level is higher.

Hypothesis 5b: The public value's indirect effect on life satisfaction via organizational citizenship behavior should be stronger if the employee common good orientation level is higher.

\section{Data collection}

Our empirical work is based on data of the 2015 Swiss Public Value Atlas. The Public Value Atlas makes transparent the contributions of private and public organizations, non-governmental organizations, and public administrations to the common good (Public Value Atlas Switzerland, 2015). Survey participants assessed these entities via an online survey reflecting Meynhardt's four public value dimensions. Data were collected over a four-week period between June and July 2015 by Intervista, a Swiss market research institute with a panel of Swiss citizens that is representative of age, gender, education, and geographic region. Prior to the main survey, the questionnaire was tested in a qualitative $(N=5)$ and quantitative pretest $(N=100)$ to check the adequacy of the study lengths as well as the questions' comprehensibility. Respondents were limited to individuals from the Public Value Atlas data-set who are employees. The final sample consisted of 1045 respondents between 18 and 67 years $(M=43.26$ years, $\mathrm{SD}=11.95)$. Of the respondents, $48 \%$ were female and $52 \%$ male. 


\section{Measures}

\section{Life satisfaction}

Our dependent variable, life satisfaction, is based on the single-item measure How satisfied are you in general with your life? This standard item is often used in studies and has been found to be an inclusive and valid measure of general life satisfaction (Bergkvist \& Rossiter, 2007; Nagy, 2002; Wanous, Reichers, \& Hudy, 1997). The employees were asked to evaluate this question on a six-point scale $(1=$ completely dissatisfied to $6=$ completely satisfied $)$.

\section{Public value}

We assessed our independent variable, public value, with validated measures from Meynhardt's psychology-based public value approach, which has been used in various settings to evaluate the perceptions of an organization's contribution to the common good (Meynhardt \& Bartholomes, 2011). Since anchor items to measure public value could be found in a previous factor analysis, we used these anchor single-item measures for each public value dimension. We asked respondents whether the organization they work for (1) behaves decently (the moral-ethical public value dimension, which corresponds to an individual's motivation for positive self-concept and self-worth in the social domain), (2) does good work in its core business (the utilitarian-instrumental public value dimension, which corresponds to an individual's motivation to understand, control, and predict their environment), (3) contributes to social cohesion in Switzerland (the political-social public value dimension, which corresponds to an individual's motivation for positive relationships, relatedness, and belonging), and (4) contributes to quality of life in Switzerland (the hedonistic-aesthetical public value dimension, which corresponds to an individual's motivation for positive emotions and avoidance of negative feelings). Respondents answered the items on a six-point scale ( $1=$ disagree to $6=$ agree $)$. Finally, we calculated organizational public value by averaging the unweighted mean across the four public value dimensions.

\section{Work engagement}

We measured work engagement with the German version of the nine-item Utrecht Work Engagement Scale (Schaufeli \& Bakker, 2004b), which is the most widely used instrument to measure work engagement (Schaufeli et al., 2002). We included three items for each of three aspects of work engagement: vigor, dedication, and absorption. Vigor refers to high levels of energy, zest, and stamina when working, as well as endurance in difficult situations. Dedication refers to feelings of inspiration, pride, and passion regarding one's work. Absorption refers to a sense of being intensely preoccupied with and fully concentrated on one's work, such that time flies and people have problems distancing themselves from their work (Caesens 
et al., 2014; Culbertson, Mills, \& Fullagar, 2012; Schaufeli et al., 2002). Examples of items are At my work, I feel bursting with energy (vigor), My job inspires me (dedication), and I feel happy when I am working intensely (absorption). Answers were given on a seven-point scale $(1=$ never to 7 = always $)$.

\section{Organizational citizenship behavior}

We measured organizational citizenship behavior with an established and validated German organizational citizenship behavior instrument (FELA-S) (Staufenbiel \& Hartz, 2000). We concentrated on civic virtue, which refers to the responsible participation in the life of the organization. This involvement includes an employee's regular participation in meetings and gatherings of the organization as well as his or her focus on new developments in the organization, creativity in improving the quality of work, and readiness to receive training and initiate problem-solving in the organization. It comprises five items, such as I make innovative suggestions for improving quality in the department $(1=$ completely incorrect to $7=$ completely correct).

\section{Employee common good orientation}

We measured employee common good orientation with four items. Employees used a six-point scale ( $1=$ wrong to $6=$ right $)$ to evaluate the items. I am concerned that the common good receives too little consideration in Switzerland, I have a clear idea of the common good, A common good orientation is important for companies to be successful in the long term, and I prefer to work for an organization/a company that has a focus on the common good even if I would thereby earn less money. The first item was developed in accordance to the Swiss Worry Barometer (gfs. bern, 2015) an index which annually tracks people's concerns about different topics in Switzerland. The other items were derived from the ethical decision-making literature which used very similar items, e.g. 'Ethics and social responsibility are essential for long term profitability' (Chung, Eichenseher, \& Taniguchi, 2008; Singhapakdi, Vitell, Rallapalli, \& Kraft, 1996; Vitell \& Paolillo, 2004).

\section{Control variables}

In accordance with previous life satisfaction studies, we considered several control variables. We controlled for respondent age as a continuous variable; for sex (male $=0$, female $=1$ ), household size (in number of residents), income ( groups, ranging from a gross monthly income of less than CHF 3000 to more than CHF 12,000), and education (nine groups, ranging from no school-leaving certificate to high tertiary education); for whether the respondent is a supervisor in the organization (no $=0$, yes $=1$ ), has a part-time $(=0)$ or a full-time $(=1)$ job; and how long the respondent has been working for the organization (in years). 
We also controlled for employee health by considering the number of sick days taken in 2014, and for organization size (number of employees per organization). Finally, we controlled for the organization's industry by considering 31 industries.

\section{Data analysis}

Our analysis consists of four parts. We began with reliability tests for our constructs public value, work engagement, organizational citizenship behavior, and common good orientation. We then presented descriptive statistics and correlations for the variables included in our regression models. Then, we investigated the mediating roles of work engagement and organizational citizenship in the relationship between an organization's public value and employee life satisfaction. To test the effects for mediation hypotheses, we used standard mediated regression techniques and followed the procedure suggested by Baron and Kenny (1986) and Judd and Kenny (1981). Testing for partial mediation requires three regression equations. The first equation needs to establish an effect between the independent variable and the outcome variable that can be mediated; the second equation needs to show that the independent variable is correlated with the mediator variable; and the third equation needs to constitute that the mediator affects the dependent variable while both independent and mediator variables are used as predictors. While for a complete mediation effect the independent variable must not affect the dependent variable when the mediator is controlled, a partial mediation is indicated when the independent variable's impact on the dependent variable is reduced, but is still significant when the mediator is controlled. Baron and Kenny (1986) suggest that partial mediation is likely the norm in psychology research. In addition, we used the Sobel test to investigate the formal significance of the mediation effects.

Finally, we tested Hypotheses $4 \mathrm{a}$ and $4 \mathrm{~b}$ via moderated regression analysis. Hypotheses $5 \mathrm{a}$ and $5 \mathrm{~b}$ are moderated mediation hypotheses, which means that the mediating process between public value as independent variable and life satisfaction as dependent variable depends on the strength of employee common good orientation as moderator variable. To test the moderated mediation effect (consistent with Preacher, Rucker, \& Hayes, 2007), we analyzed the conditional indirect effect. Three conditions must be fulfilled. First, public value must significantly affect life satisfaction. Second, public value's interaction with employee common good orientation must significantly affect the mediator. Third, the mediator must show a significant relationship with life satisfaction. If all conditions are fulfilled, the investigation may examine whether public value's indirect effect on life satisfaction via each mediator differs for employees across high and low employee common good orientation levels. We used a Stata macro for moderated mediation analysis (Preacher et al., 2007), which uses bootstrapping to test the conditional indirect effect for significance at high, middle, and low moderator variable levels. 
The subdivision into three groups is done by considering the standard deviation above and below the mean score.

\section{Results}

Table 1 shows Cronbach's $\alpha$ reliability estimates for each construct, as well as the respective means and standard deviations. We tested the variables' reliability by calculating the Cronbach's $\alpha$ coefficients for the measures of public value ( $\alpha=0.87)$, organizational citizenship behavior $(\alpha=0.86)$, work engagement $(\alpha=0.94)$, and employee common good orientation $(\alpha=0.67)$. Each measure was above the tolerance level of 0.60 , confirming a sufficient degree of reliability.

Tables 2 and 3 provide descriptive statistics and the correlation matrix. The results indicate that Swiss employees show high self-reported life satisfaction levels $(M=4.90, \mathrm{SD}=0.80)$. Most employees evaluated the public value of their

Table 1. Reliability coefficients.

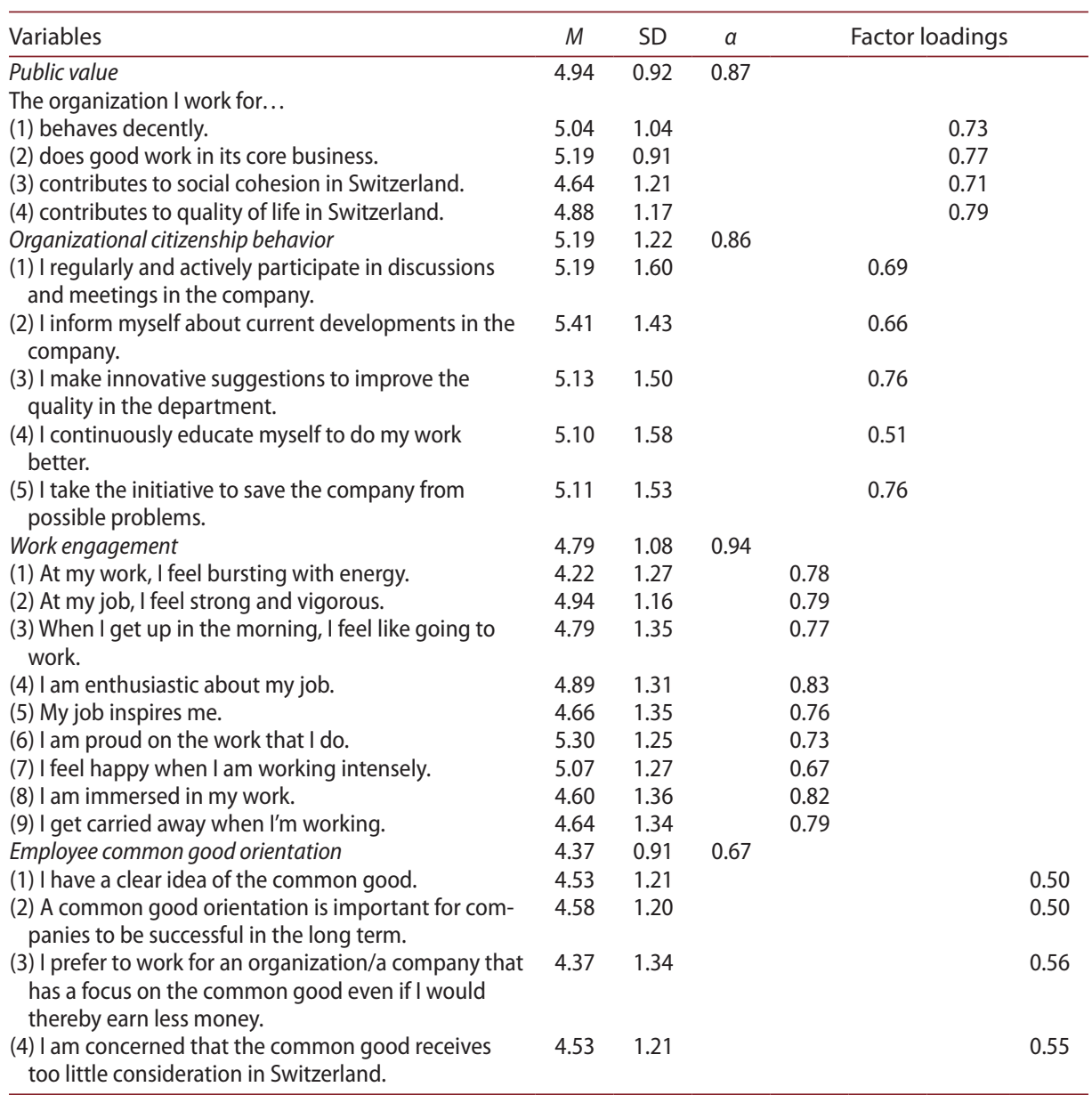

Notes: $\mathrm{SD}=$ standard deviation; $a=$ Cronbach's alpha. Rotated factor loadings, Rotation: orthogonal varimax (Kaiser off). Entries calculated with Stata 14. 
Table 2. Descriptive statistics.

\begin{tabular}{lccccc}
\hline Variables & $N$ & $M$ & SD & Min. & Max. \\
\hline Life satisfaction & 1045 & 4.903 & 0.803 & 1 & 6 \\
Public value & 1045 & 4.940 & 0.923 & 1.25 & 6 \\
Work engagement & 1045 & 4.790 & 1.077 & 1 & 7 \\
OCB & 1045 & 5.186 & 1.224 & 1 & 7 \\
CGO & 1045 & 4.370 & 0.913 & 1.25 & 6 \\
Age & 1045 & 43.259 & 11.948 & 18 & 67 \\
Sex (female) & 1045 & 0.479 & 0.500 & 0 & 1 \\
Household size & 1045 & 2.304 & 1.036 & 1 & 4 \\
Education & 1045 & 7.198 & 1.512 & 2 & 9 \\
Income & 1045 & 4.269 & 1.232 & 1 & 6 \\
Being supervisor & 1045 & 0.618 & 0.486 & 0 & 1 \\
Work years & 1045 & 10.091 & 9.674 & 0 & 46 \\
Full-time job & 1045 & 0.655 & 0.476 & 0 & 1 \\
Sick days & 1045 & 3.851 & 10.163 & 0 & 120 \\
Organization size & 1045 & $6,324.176$ & $29,420.630$ & 1 & 600,000 \\
Industry & 1045 & - & - & 1 & 31 \\
\hline
\end{tabular}

Notes: $\mathrm{OCB}=$ Organizational citizenship behavior; $\mathrm{CGO}=$ Employee common good orientation.

employing organization positively $(M=4.94, \mathrm{SD}=0.92)$. The potential mediators work engagement $(M=4.79, \mathrm{SD}=1.08)$ and organizational citizenship behavior $(M=5.19, \mathrm{SD}=1.22)$ and the potential moderator employee common good orientation $(M=4.37, \mathrm{SD}=0.91)$ showed above-average means. The respondents had relatively high education levels and had been working for their organization on average for more than 10 years. More than half of the employees had supervisor tasks in their organizations $(M=0.62, \mathrm{SD}=0.49)$ and more than $60 \%$ worked full-time $(M=0.66, \mathrm{SD}=0.48)$. On average, employees had taken four sick days $(M=3.85, \mathrm{SD}=10.16)$. Table 4 provides an overview of the industries in which employees work.

The correlation analysis provides first evidence of significant and positive relationships between life satisfaction and the mediator variables work engagement $(r=0.37)$ and organizational citizenship behavior $(r=0.28)$. Further, public value is significantly positively related to life satisfaction $(r=0.28)$ and the mediators work engagement $(r=0.40)$ and organizational citizenship behavior $(r=0.35)$. Sex, age, household size, and work years are positively related to life satisfaction, public value, and the mediator variables, while health is negatively related to them. The moderator variable, employee common good orientation, is positively related to public value, work engagement, organizational citizenship behavior, and life satisfaction.

We present results of the mediated regression analysis in Table 5. We first ran a regression equation (base model) that corresponds to our public valuelife satisfaction link. Equation 1's results show the positive relationship between public value as independent variable and life satisfaction as dependent variable $(b=0.229 ; p<0.01)$, confirming Hypothesis 1 . Among the controls, sex, education, income, and work years are significantly and positively related to life satisfaction.

Equation 2a indicates that public value is positively associated with the mediator work engagement $(b=0.504 ; p<0.01)$. Age, sex, household size, and having a 


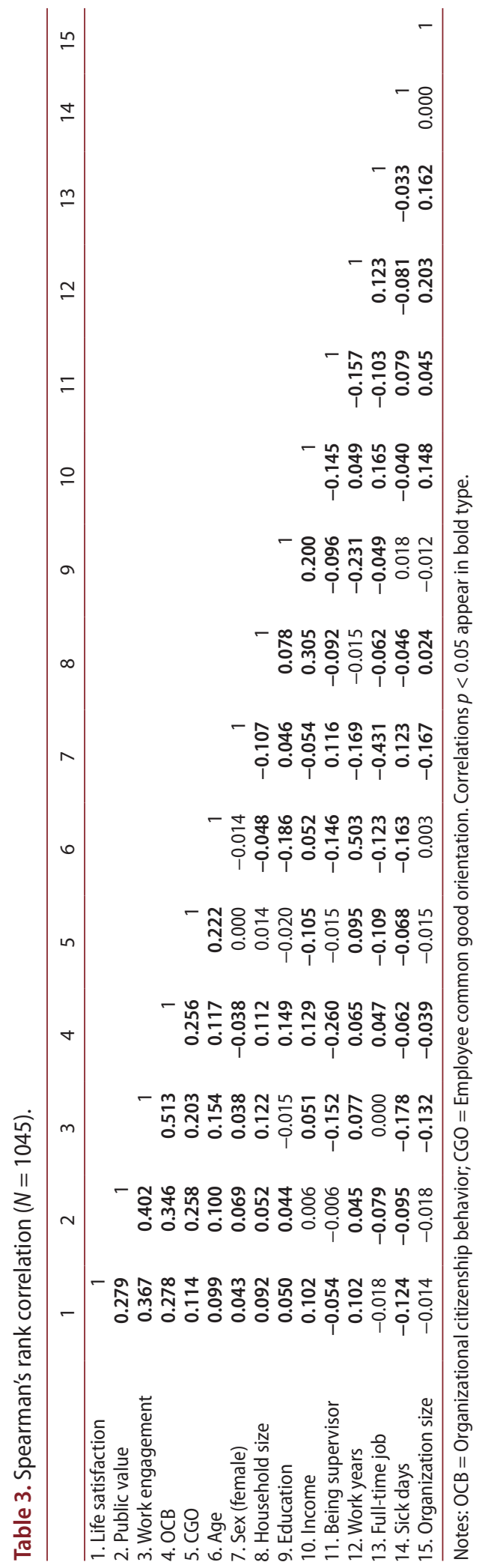


Table 4. Industries.

\begin{tabular}{lrrr}
\hline Industry & $N$ & $\%$ & Cum. \\
\hline Agriculture and forestry & 5 & 0.48 & 0.48 \\
Food and beverages industry & 18 & 1.72 & 2.20 \\
Textiles industry & 6 & 0.57 & 2.78 \\
Woodworking, esp. paper and printing & 17 & 1.63 & 4.40 \\
Chemical industry & 13 & 1.24 & 5.65 \\
Pharmaceutical industry & 24 & 2.30 & 7.94 \\
Metal industry & 22 & 2.11 & 10.05 \\
Electrical and optical industry, esp. watch manufacturing & 7 & 0.67 & 10.72 \\
Electrical industry & 19 & 1.82 & 12.54 \\
Engineering & 34 & 3.25 & 15.79 \\
Automotive & 14 & 1.34 & 17.13 \\
Energy provider & 11 & 1.05 & 18.18 \\
Water supply & 3 & 0.29 & 18.47 \\
Construction & 48 & 4.59 & 23.06 \\
Retail & 64 & 6.12 & 29.19 \\
Transport & 73 & 6.99 & 36.17 \\
Gastronomy & 23 & 2.20 & 38.37 \\
Media and publishing & 23 & 2.20 & 40.57 \\
Telecommunications & 29 & 2.78 & 43.35 \\
Information technology & 46 & 4.40 & 47.75 \\
Finance industry, esp. insurances & 46 & 3.16 & 50.91 \\
Finance industry, esp. banks & 33 & 56.65 \\
Real estate & 60 & 5.74 & 57.70 \\
Freelance and technical services & 11 & 1.05 & 58.28 \\
Public administration & 6 & 0.57 & 70.91 \\
Education and teaching, esp. universities, and colleges & 132 & 12.63 & 73.97 \\
Education and teaching, esp. schools & 32 & 3.06 & 80.77 \\
Healthcare & 71 & 6.79 & 94.16 \\
Homes and social services & 140 & 13.40 & 97.51 \\
Leisure (art, entertainment, recreation) & 35 & 3.35 & 100 \\
Interest groups & 17 & 1.63 & \\
Total & 9 & 0.86 & \\
\hline
\end{tabular}

full-time job are also positively related to work engagement, while being a supervisor is negatively related to work engagement. Equation $2 \mathrm{~b}$ demonstrates the partially mediating role of work engagement in the relationship between public value and life satisfaction. While controlling for work engagement $(b=0.223$; $p<0.01$ ), we find the link between public value and life satisfaction shows a reduced effect of nearly $49 \%$, from $b=0.229$ to $b=0.116$ ( $p<0.01$ ), confirming Hypotheses 2a and 2b.

We found a significant positive relationship between public value and the second mediator organizational citizenship behavior, as Equation 3a's results in Table 5 show $(b=0.404 ; p<0.01)$. This finding corresponds to our Hypothesis 3a. Among the control variables, age, sex, household size, education, income, and having a full-time job are significantly positively related to organizational citizenship behavior, while being a supervisor in the organization is negatively related to organizational citizenship behavior. The regression Equation 3b shows that organizational citizenship behavior is positively linked to life satisfaction $(b=0.175 ; p<0.01)$, confirming the effect of the mediator on the outcome variable. Further, in the third regression equation, public value's effect on life satisfaction is reduced by nearly $24 \%$, from $b=0.229$ to $\mathrm{b}=0.175(p<0.01)$ when organizational 
Table 5. Results of mediated regression analysis.

\begin{tabular}{|c|c|c|c|c|c|c|}
\hline \multirow{4}{*}{$\begin{array}{l} \\
\\
\text { Dependent } \\
\text { variable: }\end{array}$} & \multirow{3}{*}{$\begin{array}{c}\text { Base } \\
\text { model } \\
\begin{array}{c}\text { Life satisfac- } \\
\text { tion }\end{array}\end{array}$} & \multicolumn{2}{|c|}{ Work engagement } & \multicolumn{2}{|c|}{ OCB } & \multirow{3}{*}{$\begin{array}{c}\text { Full } \\
\text { model } \\
\begin{array}{c}\text { Life satisfac- } \\
\text { tion }\end{array}\end{array}$} \\
\hline & & \multicolumn{2}{|c|}{ models } & \multicolumn{2}{|c|}{ models } & \\
\hline & & $\begin{array}{c}\text { Work } \\
\text { engagement }\end{array}$ & $\begin{array}{l}\text { Life satisfac- } \\
\text { tion }\end{array}$ & OCB & $\begin{array}{l}\text { Life satisfac- } \\
\text { tion }\end{array}$ & \\
\hline & [1] & {$[2 \mathrm{a}]$} & {$[2 \mathrm{~b}]$} & [3a] & {$[3 \mathrm{~b}]$} & [4] \\
\hline $\begin{array}{l}\text { Independent } \\
\text { variable: }\end{array}$ & & & & & & \\
\hline $\begin{array}{l}\text { Public value } \\
\text { Mediators: }\end{array}$ & $0.229^{* * *}$ & $0.504^{* * *}$ & $0.116^{* * *}$ & $0.404^{* * *}$ & $0.175^{* * *}$ & $0.106^{* * *}$ \\
\hline $\begin{array}{l}\text { Work engage- } \\
\text { ment }\end{array}$ & & & $0.223^{* * *}$ & & & $0.192^{* * *}$ \\
\hline $\begin{array}{l}\text { OCB } \\
\text { Controls: }\end{array}$ & & & & & $0.134^{* * *}$ & $0.065^{* * *}$ \\
\hline Age & 0.003 & $0.012^{* * *}$ & 0.000 & $0.006^{*}$ & 0.002 & 0.000 \\
\hline Sex (female) & $0.153^{* * *}$ & $0.236^{* * *}$ & $0.101^{*}$ & -0.055 & $0.161^{* * *}$ & $0.112^{* *}$ \\
\hline Household size & $0.045^{*}$ & $0.117^{* * *}$ & 0.019 & $0.071^{* *}$ & 0.036 & 0.018 \\
\hline Education & $0.029^{*}$ & -0.018 & $0.033^{* *}$ & $0.084^{* * *}$ & 0.018 & 0.027 \\
\hline Income & $0.037^{*}$ & 0.004 & $0.036^{*}$ & $0.074^{* *}$ & 0.027 & 0.031 \\
\hline $\begin{array}{l}\text { Being super- } \\
\text { visor }\end{array}$ & -0.058 & $-0.278^{* * *}$ & 0.004 & $-0.537^{* * *}$ & 0.014 & 0.030 \\
\hline Work years & $0.007^{* *}$ & -0.003 & $0.008^{* * *}$ & 0.000 & $0.007^{* *}$ & $0.008^{* * *}$ \\
\hline Full-time job & 0.040 & $0.170 * *$ & 0.002 & 0.126 & 0.023 & -0.001 \\
\hline Sick days & $-0.004^{*}$ & -0.001 & $-0.004^{*}$ & 0.002 & $-0.005^{* *}$ & $-0.004^{*}$ \\
\hline Constant & $2.818^{* * *}$ & $1.651^{* * *}$ & $2.450^{* * *}$ & $2.409 * * *$ & $2.495^{* * *}$ & $2.346^{* * *}$ \\
\hline $\operatorname{Adj} . R^{2}$ & 0.121 & 0.224 & 0.190 & 0.191 & 0.154 & 0.195 \\
\hline F & $4.501^{* * *}$ & $8.354^{* * *}$ & $6.815^{* * *}$ & $6.998^{* * *}$ & $5.519 * * *$ & $6.891^{* * *}$ \\
\hline Mediation in \% & & & 49.14 & & 23.63 & \\
\hline Sobel test (z) & & & $7.827^{* * *}$ & & $5.357^{* * *}$ & \\
\hline
\end{tabular}

Notes: $\mathrm{OCB}=$ Organizational citizenship behavior; $\mathrm{CGO}=$ Employee common good orientation.

Mediation in $\%=\%$ of total effect. $N=1045$. Results of the control variables organization size and industry were not reported. Models were calculated with Stata 14.

Significant levels:

${ }^{*} p<0.1 ;{ }^{* *} p<0.05 ;{ }^{* * *} p<0.01$.

citizenship behavior is controlled for. Consistent with Hypothesis $3 \mathrm{~b}$, we found a partially mediating effect of organizational citizenship behavior on the relationship between public value and life satisfaction. Results of Model 4 indicate that the effect of the first mediator, work engagement, on life satisfaction is strongest.

Tables 6 and 7 present the results of the moderation analysis and the moderated mediation analysis. We examined whether the interaction of organizational public value with employee common good orientation is significant in predicting each mediator. The results presented in Table 6 show that the interaction term for organizational public value with employee common good orientation is significant in predicting work engagement $(b=0.073 ; p<0.05)$ and organizational citizenship behavior $(b=0.069 ; p<0.1)$, in terms of a stronger relationship when employee common good orientation is stronger, confirming Hypotheses $4 \mathrm{a}$ and 4 b. Figures 3 and 4 display the interaction diagrams, which make transparent the employee common good orientation's moderating influence on work engagement and organizational citizenship behavior for different organizational public value levels. 
Table 6. Results of moderated regression analysis.

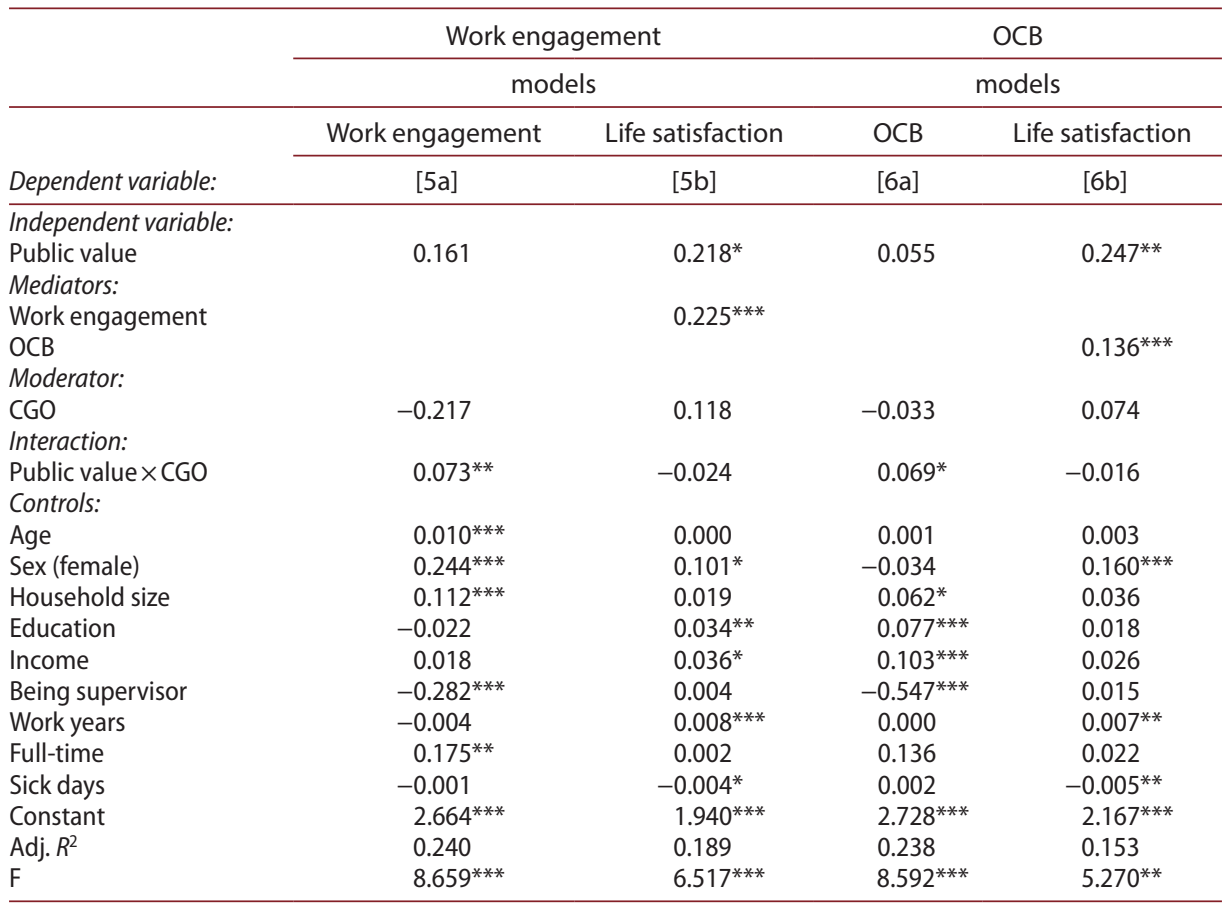

Notes: $\mathrm{OCB}=$ Organizational citizenship behavior; $\mathrm{CGO}=$ Employee common good orientation.

$N=1045$. Results of the control variables organization size and industry were not reported. Models were calculated with Stata 14.

Significant levels:

${ }^{*} p<0.1 ;{ }^{* *} p<0.05 ;{ }^{* * *} p<0.01$.

Table 7. Results for conditional indirect effects.

\begin{tabular}{|c|c|c|c|c|c|c|c|c|}
\hline \multirow[b]{2}{*}{ Mediator } & \multirow[b]{2}{*}{ Moderator } & \multirow[b]{2}{*}{ Level } & \multicolumn{6}{|c|}{ Dependent variable: life satisfaction } \\
\hline & & & $\begin{array}{c}\text { Boot } \\
\text { indirect } \\
\text { effect }\end{array}$ & SE & $z$ & $P>|z|$ & LL 95\% Cl & UL 95\% Cl \\
\hline $\begin{array}{l}\text { Work } \\
\text { Engage- } \\
\text { ment }\end{array}$ & CGO & $\begin{array}{l}\text { Low }(-1 \\
\text { SD) }\end{array}$ & 0.093 & 0.016 & 5.77 & 0.000 & 0.062 & 0.125 \\
\hline $\begin{array}{l}\text { Work } \\
\text { Engage- } \\
\text { ment }\end{array}$ & CGO & Middle $(M)$ & 0.108 & 0.016 & 6.92 & 0.000 & 0.078 & 0.139 \\
\hline $\begin{array}{l}\text { Work } \\
\text { Engage- } \\
\text { ment }\end{array}$ & CGO & $\begin{array}{l}\text { High (+1 } \\
\text { SD) }\end{array}$ & 0.123 & 0.019 & 6.63 & 0.000 & 0.087 & 0.160 \\
\hline OCB & CGO & $\begin{array}{l}\text { Low }(-1 \\
\text { SD) }\end{array}$ & 0.040 & 0.009 & 3.39 & 0.001 & 0.017 & 0.063 \\
\hline OCB & CGO & Middle $(M)$ & 0.048 & 0.009 & 4.38 & 0.000 & 0.027 & 0.070 \\
\hline OCB & CGO & $\begin{array}{l}\text { High (+ } 1 \\
\text { SD) }\end{array}$ & 0.057 & 0.011 & 4.37 & 0.000 & 0.031 & 0.083 \\
\hline
\end{tabular}

Notes: $\mathrm{LL}=$ lower limit of confidence interval $(\mathrm{Cl}) ; \mathrm{UL}=$ upper limit of $\mathrm{Cl} ; \mathrm{OCB}=$ Organizational citizenship behavior; CGO $=$ Employee common good orientation. $N=1045$. Bootstrap sample size $=5000$. Models were calculated with Stata 14.

According to Hypotheses 5a and 5b, public value's indirect effect on life satisfaction via each mediator should be stronger if the employee common good orientation level is higher. Before we estimated conditional indirect effects, we checked 


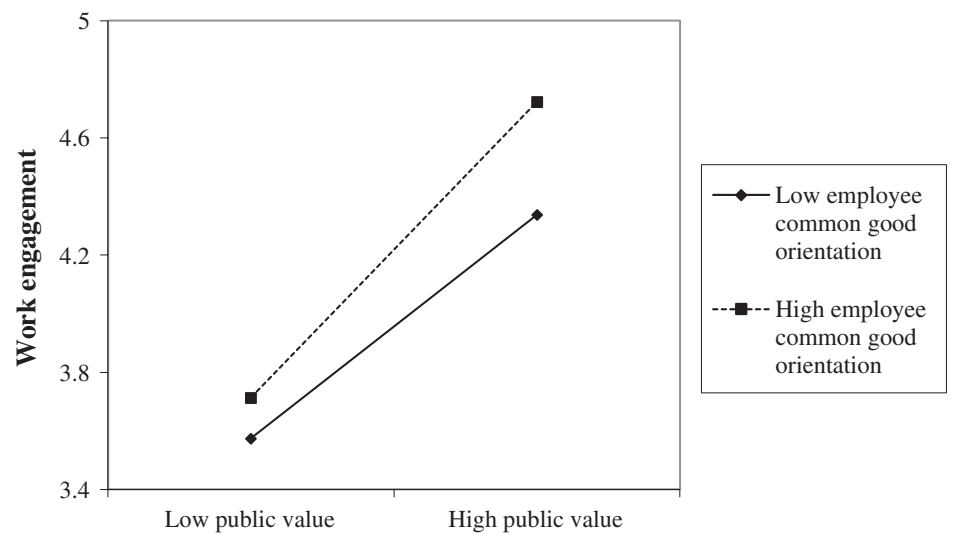

Figure 3. Interaction between an organization's public value and employee common good orientation for the prediction of work engagement.

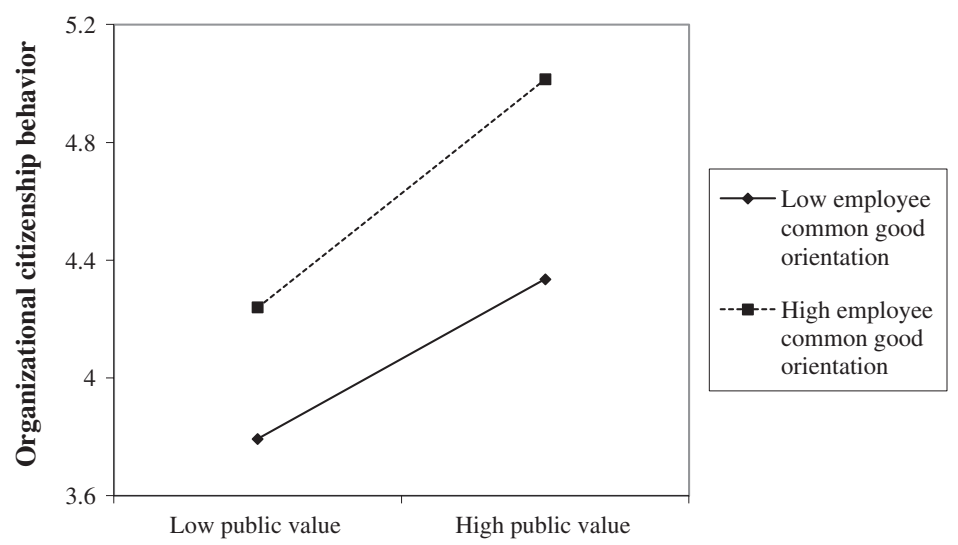

Figure 4. Interaction between an organization's public value and employee common good orientation for the prediction of organizational citizenship behavior.

the three above-mentioned conditions. First, as noted, we found a positive and significant relationship between public value and life satisfaction, satisfying condition 1 . Second, as reported, we found evidence for a positive moderation effect on work engagement and organizational citizenship behavior, satisfying condition 2 for both variables. Third, as reported in Table 5, we found that all mediators significantly and positively relate to life satisfaction. Thus, on the basis of these results, we first examined whether public value's indirect effect on life satisfaction via work engagement differs for employees across high and low common good orientation levels. We then examined whether public value's indirect effect on life satisfaction via organizational citizenship behavior differs for employees across high and low common good orientation levels. The bootstrap results $($ size $=5000)$ in Table 7 show that, for work engagement and organizational citizenship behavior, the conditional indirect effect is positive and different from zero for all employee 
common good orientation levels, but that the effect is stronger at higher employee common good orientation levels, confirming Hypotheses 5a and 5b.

\section{Discussion and conclusion}

\section{Discussion of the findings}

Our study is a response to calls for more research into the outcomes of common good practices (e.g. CSR, public value, sustainability) at the individual level with a focus on important internal stakeholders, such as employees. Glavas and Kelley (2014) have emphasized that the literature contains only a small number of individual-level mediation and moderation analyses. Building on Meynhardt's public value concept, we explored the influence of an organization's public value on employee life satisfaction via the mediators work engagement and organizational citizenship behavior. Further, we considered employee common good orientation as moderator in order to understand how employee common good orientation influences the relationships among the other variables.

We found evidence that organizational public value positively influences employee life satisfaction, and that work engagement and organizational citizenship behavior play a partially mediating role in explaining their positive relationship. Further, we found evidence that employee common good orientation significantly moderates the relationship between an organization's public value and the mediators work engagement and organizational citizenship behavior, in terms of a stronger relationship when employee common good orientation is stronger. We found an interesting result concerning the conditional indirect effects: an organization's public value's indirect effect on employee life satisfaction via work engagement and organizational citizenship behavior is stronger at higher employee common good orientation levels, implying that employees are satisfied when their own values and the organization's values are congruent.

The results show the positive effects of organizations' common good practices on their employees. Employees find relevant not only how an organization considers its interests, but also how it responds to the public's need for social cohesion or high quality of life. If an organization contributes to the common good in its core business, it may also generate a positive reputation in the public (Müller \& Brieger, 2016), which in turn should correspond to favorable work-related self-concepts among its employees. Identity theory holds that individuals can derive a positive identity by belonging to a social collective. When an organization is appreciated by the public because it contributes to the common good, employees can develop a positive self-concept from their organizational membership. If an employee benefits from organizational membership, this benefit may also positively affect employee attitudes toward the employing organization, as we have shown here.

We found empirical evidence that organizations can benefit in various ways when they respond to their employees' basic needs. In particular, our results show that employees are more engaged and report greater initiative at work when 
their basic needs are met. These are key findings, since engaged and responsible workers are more productive and more creative, are sick less often, and are a key and convincing communication medium (as ambassadors) with external stakeholders. Employees who are satisfied with their work will more likely represent their employing organization positively and better promote their organization.

\section{Managerial implications}

Our results provide important implications for management practice. Management should focus more on public value creation throughout its internal and external activities. To strengthen employee commitment, organizations could respond to the finding that employee engagement and thereby life satisfaction is influenced by an employee's sensitivity to the common good (Dögl \& Holtbrügge, 2013; Hofman \& Newman, 2013). By launching public value programs for employees, for instance by jointly reflecting on the organization's public value orientation and searching for ways to create more public value, organizations could do something good for themselves, employees, and the public. Furthermore, organizations could promote opportunities for employees to actively experience the organization's contribution toward the common good, for example by initiating a dialogue with society (e.g. stakeholder dialogue) and establishing measures where employees receive direct feedback on the impact of the organization.

Moreover, management should clearly communicate to employees an organization's identity as reflected in collectively shared values and beliefs. Employees are not always aware of how the employing organization fulfills basic needs and contributes to the common good. This practice starts with the strategy and the business model, where the reasons for certain products' and services' benefit to society often remain implicit. As leadership advocates call for an inspiring, visionary, and transformational leadership style (Bass, 1985), the explicit integration of a public value narrative would be a natural measure to positively affect employees. From a managerial perspective, it is also important to communicate this public value proposition to all stakeholders, so as to better signal and demonstrate credibility to all parties involved. This communication may be reflected in both non-financial reporting approaches (e.g. sustainability reports, materiality matrix) and in internal HR policies and rewards systems that underscore this mindset.

\section{Contributions, limitations and future research}

Our research not only supports new directions of fostering common good practices or systematic public value management within an organization, it also contributes to further research. We contribute to the literature by combining and analyzing the relationships of variables and constructs not previously explored. Very little is known concerning the roles of mediator and moderator variables in the relationship between an organization's common good practices and employee 
satisfaction. Further, the public value concept has been used to measure an organization's common good contribution in the perceptions of its employees. The public value concept has the advantage of being usable not only for research with employees in the private sector, but also for employees in the public sector or in non-governmental organizations. Finally, this study is the first to empirically investigate employees' general life satisfaction as an outcome of common good practices. Our results can also spur more fundamental theorizing on how public value serves as a mechanism to integrate individuals into society and to help them to grow. From a social theory perspective, an organization's public value can be seen as formative for people concerning how their society functions. Such a perspective should lead to a more general reflection about how people develop a sense of belonging in society and identity via their workplaces (He \& Brown, 2013) and, thus, how society constitutes itself (Giddens, 1984) via people's workplace experiences.

Despite the value of our findings, our research has limitations. The first limitation concerns the source of our data. Since we relied on data from a single source, common method bias can be a problem (Podsakoff, MacKenzie, Lee, \& Podsakoff, 2003). However, in our view, common method bias is not a significant problem in our study for several reasons. First, we reduced the possibility of socially desirable responses by ensuring our respondents of anonymity and by explaining that the survey questions had no right or wrong answers. Second, following Podsakoff et al.s (2003) advice, we included different scale formats, some reverse-coded items, and open questions in the survey. Third, the questionnaire items, which were formulated in the country's language, were clear, precise, and easy to understand. To check our survey measures' validity and the adequacy of the study lengths, we used feedback from a qualitative $(N=5)$ and quantitative pretest $(N=100)$. Fourth, our questionnaire items were part of a large-scale questionnaire, which reduces the likelihood that 'respondents would have been able to guess the purpose of the study and forced their answers to be consistent' (Mohr \& Spekman, 1994, p. 147). In addition, to reduce complexity respondents were shown only a limited number of questionnaire items per screen. Moreover, different item sections were introduced by a short text to help respondents better understand the content and the transition from the previous questionnaire item section to the next (Podsakoff et al., 2003). Fifth, following the advice of Chang, van Witteloostuijn, and Eden (2010), we specified a more complex model by adding mediation and moderating effects. Our empirical results demonstrate that respondents have not rated the items in a thoughtless manner as either low or high. Sixth, our study considered several objective control variables - such as age, sex, household size, income, education, full-time or part-time job, years in the organization, and the organization's industry by considering 31 industries - that allowed us to control for shared aspects in cognition and thus differences in response bias across groups. Seventh, from a post hoc perspective, we employed a one-factor test for our sample (Harman, 1976). To perform Harman's single-factor test, we entered 
all variables into a principal components factor analysis. It is assumed that common method bias is indicated when only one factor or one general factor explains most of the total variance (Podsakoff et al., 2003). In contrast, the higher the number of extracted dimensions, the less likely it is that common method bias is responsible for systematic variance in the data (Podsakoff \& Organ, 1986). Our Harman's one-factor test on all variables extracted four factors with eigenvalues of 1 or more, with the first factor explaining only $38 \%$ of total variance. Further, we employed a principal component factor analysis using varimax rotation (see Table 1). Results of the rotated factor loadings show that each construct item loaded on different factors. Therefore, in our view, common method bias does not present a significant threat to the study.

The second limitation of our study concerns the study design. Since we applied a cross-sectional study design, the presumed mediating causal relationships might not be found in a longitudinal study design. A longitudinal study could provide stronger support for the proposed model. Furthermore, despite in-depth theoretical considerations that speak for the proposed model, alternative directions could be possible. For instance, an individual's common good orientation might bias his or her perceptions of the organization's public value in a negative or positive way. Further, work engagement or organizational citizenship behavior might also influence how organizational public value is perceived. More engaged workers could also positively affect organizational citizenship behavior. To clarify these points, more research is needed.

The third limitation concerns the applied constructs for life satisfaction and employee common good orientation. For our dependent variable, we used a single-item life satisfaction measure. Even if previous research (e.g. Cheung \& Lucas, 2014; Jovanović, 2016) confirms that our measure is highly valid and strongly associated with multifaceted life satisfaction scales, future investigations should take into account that life satisfaction is multidimensional and thus use multifaceted life satisfaction scales like the Satisfaction With Life Scale (Diener, Emmons, Larsen, \& Griffin, 1985). Further, even if the Cronbach's $\alpha$ reliability is satisfactory, future research should either further test the validity and reliability of the common good orientation scale or use better established constructs of the ethical decision-making literature to measure employee common good orientation. For instance, the Machiavellianism Scale (which measures an individual's emotional involvement with other people), the Attitude Towards Business Ethics Questionnaire (ATBEQ) research instrument (which measures ethical business attitudes), the Perceived Role of Ethics and Social Responsibility (PRESOR) scale (which measures an individual's stakeholder view and stockholder view), or the Ethics Position Questionnaire (which measures an individual's ethical idealism and relativism) would be very good measures for further analyses (Fernando, Dharmage, \& Almeida, 2008; O’Fallon \& Butterfield, 2005; Redfern \& Crawford, 2004; Simmons et al., 2013; Singhapakdi et al., 1996; Vitell \& Paolillo, 2004; Vitell, Paolillo, \& Thomas, 2003). 
A fourth limitation is the possibility of social desirability that could have biased the respondents' answers (Crowne \& Marlowe, 1964), which is especially common in the business ethics research field. However, we made efforts to reduce this effect. The respondents did not have to provide their organization's name and were assured that their answers would remain anonymous. We aggregated the data across different employees of organizations in Switzerland that remained unknown. This approach is both an advantage and a disadvantage. Even if anonymity is good for the data quality, we cannot link the employees to the same organization. For further research, it would be interesting to investigate larger employee groups from the same organization and to analyze, via multilevel modeling, whether the study results can be replicated across individuals and different group levels from the same organization. Further, future research could focus on employee-supervisor relationships in the context of public value creation and employ research designs that allow matching employees to their supervisor. For instance, employee perceptions of an organization's contribution to the common good can be significantly influenced by leadership characteristics and behaviors. Supervisors could influence employee perceptions of organizational public value performance by their ethical leadership or transformational leadership styles. Furthermore, supervisors with strong competencies in articulating the organization's public value goals and achievement could provide a common purpose of work, enabling employees to recognize their work's importance, which in turn has positive effects on aspects such as work engagement and organizational citizenship behavior. Further investigations aiming at in-depth understanding of how leadership attitudes and behaviors affect the relationships between organizations' common good practices and employee outcomes would provide better insights into the conditions in which public value creation occurs.

Finally, the fifth limitation of our study concerns its restriction of the study results to Switzerland. As we have shown, people in Switzerland evaluate their lives and their workplaces fairly highly. Switzerland is known for its high quality of life. Future research should investigate whether our findings can be confirmed in other informal or formal institutional environments.

In conclusion, we found evidence that an organization's public value is a resource for the organization, employees, and the public. Organizations should focus more on employee perceptions of organizational contributions to the common good. Thus, clear communication of an organization's strengths, commitments, and engagements are essential for good evaluation. Organizations should behave according to the maxim: Do good and talk about it, especially in the organization.

\section{Acknowledgement}

The authors would like to thank the editor and three anonymous reviewers for their very helpful comments and suggestions. 


\section{Disclosure statement}

No potential conflict of interest was reported by the authors.

\section{References}

Aguinis, H., \& Glavas, A. (2012). What we know and don't know about corporate social responsibility: A review and research agenda. Journal of Management, 38(4), 932-968.

Argandoña, A. (1998). The stakeholder theory and the common good. Journal of Business Ethics, 17(9/10), 1093-1102.

Ashfort, B. E., \& Mael, F. (1989). Social identity theory and the organization. The Academy of Management Review, 14(1), 20-39.

Bakker, A. B., Schaufeli, W. B., Leiter, M. P., \& Taris, T. W. (2008). Work engagement: An emerging concept in occupational health psychology. Work \& Stress, 22(3), 187-200.

Baron, R. M., \& Kenny, D. A. (1986). The moderator-mediator variable distinction in social psychological research: Conceptual, strategic, and statistical considerations. Journal of Personality and Social Psychology, 51(6), 1173-1182.

Bass, B. (1985). Leadership and performance beyond expectations. New York, NY: Free Press.

Bergkvist, L., \& Rossiter, J. R. (2007). The predictive validity of multiple-item versus single-item measures of the same constructs. Journal of Marketing Research, 44(2), 175-184.

Bhattacharya, C. B., \& Sen, S. (2004). Doing better at doing good: When, why, and how consumers respond to corporate social initiatives. California Management Review, 47(1), 9-24.

Blau, P. M. (2008). Exchange and power in social life: With a new introduction by the author (12th print). New Brunswick, NJ: Transaction Publ.

Boxx, R. W., Randall, O. Y., \& Dunn, M. G. (1991). Organizational values and value congruency and their impact on satisfaction, commitment, and cohesion: An Empirical examination within the public sector. Public Personnel Management, 20(1), 195-205.

Brammer, S., Millington, A., \& Rayton, B. (2007). The contribution of corporate social responsibility to organizational commitment. The International Journal of Human Resource Management, 18(10), 1701-1719.

Brammer, S., He, H., \& Mellahi, K. (2015). Corporate social responsibility, employee organizational identification, and creative effort: The moderating impact of corporate ability. Group \& Organization Management, 40(3), 323-352.

van den Broeck, A., Vansteenkiste, M., Witte, H.De, \& Lens, W. (2008). Explaining the relationships between job characteristics, burnout, and engagement: The role of basic psychological need satisfaction. Work \& Stress, 22(3), 277-294. doi:10.1080/02678370802393672

Caesens, G., Stinglhamber, F., \& Luypaert, G. (2014). The impact of work engagement and workaholism on well-being. Career Development International, 19(7), 813-835.

Carcello, J. V. (2009). Governance and the Common Good. Journal of Business Ethics, 89(S1), $11-18$.

Chang, S.-J., van Witteloostuijn, A., \& Eden, L. (2010). From the editors: Common method variance in international business research. Journal of International Business Studies, 41(2), $178-184$.

Cheung, F., \& Lucas, R. E. (2014). Assessing the validity of single-item life satisfaction measures: Results from three large samples. Quality of life research: An international journal of quality of life aspects of treatment, care and rehabilitation, 23(10), 2809-2818.

Choi, Y., \& Yu, Y. (2014). The influence of perceived corporate sustainability practices on employees and organizational performance. Sustainability, 6(1), 348-364. 
Chung, K. Y., Eichenseher, J. W., \& Taniguchi, T. (2008). Ethical perceptions of business students: Differences between East Asia and the USA and Among "Confucian" cultures. Journal of Business Ethics, 79(1-2), 121-132.

Collier, J., \& Esteban, R. (2007). Corporate social responsibility and employee commitment. Business Ethics: A European Review, 16(1), 19-33.

Collins, C. M., Steg, L., \& Koning, M. A. S. (2007). Customers' values, beliefs on sustainable corporate performance, and buying behavior. Psychology and Marketing, 24(6), 555-577.

Colquitt, J. A., Conlon, D. E., Wesson, M. J., Porter, C. O. L. H., \& Ng, K. Y. (2001). Justice at the millennium: A meta-analytic review of 25 years of organizational justice research. Journal of Applied Psychology, 86(3), 425-445.

Crowne, D. P., \& Marlowe, D. (1964). The approval motive: Studies in evaluative dependence. New York, NY: Wiley.

Culbertson, S. S., Mills, M. J., \& Fullagar, C. J. (2012). Work engagement and work-family facilitation: Making homes happier through positive affective spillover. Human Relations, 65(9), 1155-1177.

Dávila, M. C., \& Finkelstein, M. A. (2013). Organizational citizenship behavior and well-being: Preliminary results. International Journal of Applied Psychology, 3(3), 45-51.

Diener, E., Emmons, R. A., Larsen, R. J., \& Griffin, S. (1985). The satisfaction with life scale. Journal of Personality Assessment, 49(1), 71-75.

Dögl, C., \& Holtbrügge, D. (2013). Corporate environmental responsibility, employer reputation and employee commitment: An empirical study in developed and emerging economies. The International Journal of Human Resource Management, 25(12), 1739-1762.

Du, S., Bhattacharya, C. B., \& Sen, S. (2015). Corporate social responsibility, multi-faceted job-products, and employee outcomes. Journal of Business Ethics, 131(2), 319-335.

Edwards, J. R., \& Cable, D. M. (2009). The value of value congruence. Journal of Applied Psychology, 94(3), 654-677.

Epstein, S. (1989). Values from the perspective of cognitive-experiential self-theory. In N. Eisenberg (Ed.), Social and moral values (pp. 3-22). Hillsdale: Erlbaum.

Epstein, S. (1993). Emotion and self-theory. In M. Lewis \& J. M. Haviland-Jones (Eds.), Handbook of emotions (pp. 313-326). New York, NY: Guilford Press Sons Inc.

Epstein, S. (2003). Cognitive-experiential self-theory of personality. In I. B. Weiner, D. K. Freedheim, J. A. Schinka, \& W. F. Velicer (Eds.), Handbook of psychology (pp. 159-184). New York, NY: Wiley.

Erdogan, B., Bauer, T. N., Truxillo, D. M., \& Mansfield, L. R. (2012). Whistle while you work: A review of the life satisfaction literature. Journal of Management, 38(4), 1038-1083. doi:10.1177/0149206311429379

Farooq, O., Payaud, M., Merunka, D., \& Valette-Florence, P. (2014). The impact of corporate social responsibility on organizational commitment: Exploring multiple mediation mechanisms. Journal of Business Ethics, 125(4), 563-580. doi:10.1007/s10551-013-1928-3

Fernando, M., Dharmage, S., \& Almeida, S. (2008). Ethical ideologies of senior australian managers: An empirical study. Journal of Business Ethics, 82(1), 145-155.

Foote, D. A., \& Li-Ping Tang, T. (2008). Job satisfaction and organizational citizenship behavior (OCB). Management Decision, 46(6), 933-947. doi:10.1108/00251740810882680

Franzen, A. (2003). Environmental attitudes in international comparison: An analysis of the ISSP surveys 1993 and 2000. Social Science Quarterly, 84(2), 297-308.

Fried, Y., \& Ferris, G. R. (1987). The validity of the job characteristics model: A review and meta-analysis. Personnel Psychology, 40, 287-322.

Fritzsche, D. J., \& Oz, E. (2007). Personal values' influence on the ethical dimension of decision making. Journal of Business Ethics, 75(4), 335-343. 
gfs.bern. (2015). Credit Suisse Sorgenbarometer 2015. Retrieved from http://www.gfsbern.ch/ de-ch/Detail/category/sorgenbarometer

Ghobadian, A., Money, K., \& Hillenbrand, C. (2015). Corporate responsibility research: Past-present-future. Group \& Organization Management, 40(3), 271-294. doi:10.1177/1059601115590320

Giacalone, R. A., Jurkiewicz, C. L., \& Deckop, J. R. (2008). On ethics and social responsibility: The impact of materialism, postmaterialism, and hope. Human Relations, 61(4), 483-514. doi:10.1177/0018726708091019

Giddens, A. (1984). The constitution of society: Outline of the theory of structuration. Berkeley \& Los Angeles: University of California Press.

Glavas, A., \& Godwin, L. N. (2013). Is the perception of 'goodness' good enough? Exploring the relationship between perceived corporate social responsibility and employee organizational identification. Journal of Business Ethics, 114(1), 15-27. doi:10.1007/s10551-012-1323-5

Glavas, A., \& Kelley, K. (2014). The effects of perceived corporate social responsibility on employee attitudes. Business Ethics Quarterly, 24(02), 165-202. doi:10.5840/beq20143206

Gond, J.-P., Igalens, J., Swaen, V., \& El Akremi, A. (2011). The human resources contribution to responsible leadership: An exploration of the CSR-HR interface. Journal of Business Ethics, 98(S1), 115-132.

Grawitch, M. J., \& Barber, L. K. (2010). Work flexibility or nonwork support? Theoretical and empirical distinctions for work-life initiatives. Consulting Psychology Journal: Practice and Research, 62(3), 169-188. doi:10.1037/a0020591

Greguras, G. J., \& Diefendorff, J. M. (2010). Why does proactive personality predict employee life satisfaction and work behaviors? A field investigation of the mediating role of the selfconcordance model. Personnel Psychology, 63, 539-560.

Hackman, J. R., \& Oldham, G. R. (1980). Work redesign. Reading, MA: Addison-Wesley.

Hakanen, J. J., \& Schaufeli, W. B. (2012). Do burnout and work engagement predict depressive symptoms and life satisfaction? A three-wave seven-year prospective study. Journal of Affective Disorders, 141(2-3), 415-424. doi:10.1016/j.jad.2012.02.043

Hansen, D. S., Dunford, B. B., Boss, A. D., Boss, W. R., \& Angermeier, I. (2011). Corporate social responsibility and the benefits of employee trust: A cross-disciplinary perspective. Journal of Business Ethics, 102(1), 29-45.

Harman, H. H. (1976). Modern factor analysis (3rd ed.). Chicago, IL: The University of Chicago Press.

He, H., \& Brown, A. D. (2013). Organizational identity and organizational identification: A review of the literature and suggestions for future research. Group \& Organization Management, 38(1), 3-35. doi:10.1177/1059601112473815

Hobfoll, S. E. (2001). The influence of culture, community, and the nested-self in the stress process: Advancing conservation of resources theory. Applied Psychology: An International Review, 50(3), 337-421.

Hofman, P. S., \& Newman, A. (2013). The impact of perceived corporate social responsibility on organizational commitment and the moderating role of collectivism and masculinity: Evidence from China. The International Journal of Human Resource Management, 25(5), 631-652. doi:10.1080/09585192.2013.792861

Inglehart, R. (1995). Public support for environmental protection: Objective problems and subjective values in 43 societies. Political Science and Politics, 28(1), 57-72.

Inglehart, R. (1997). Modernization and postmodernization: Cultural, economic, and political change in 43 societies. Princeton, NJ: Princeton University Press.

Jovanović, V. (2016). The validity of the satisfaction with life scale in adolescents and a comparison with single-item life satisfaction measures: A preliminary study. Quality of life 
research: An international journal of quality of life aspects of treatment, care and rehabilitation, 25(12), 3173-3180. doi:10.1007/s11136-016-1331-5

Judd, C. M., \& Kenny, D. A. (1981). Process analysis: Estimating mediation in treatment evaluations. Evaluation Review, 5(5), 602-619. doi:10.1177/0193841X8100500502

Judge, T. A., \& Watanabe, S. (1993). Another look at the job satisfaction-life satisfaction relationship. Journal of Applied Psychology, 78(6), 939-948.

Kahn, W. A. (1990). Psychological conditions of personal engagement and disengagement at work. Academy of Management Journal, 33(4), 692-724. doi:10.2307/256287

Kim, Y., \& Kim, S.-Y. (2010). The influence of cultural values on perceptions of corporate social responsibility: Application of Hofstede's dimensions to Korean public relations practitioners. Journal of Business Ethics, 91(4), 485-500.

Kim, H.-R., Lee, M., Lee, H.-T., \& Kim, N.-M. (2010). Corporate social responsibility and employee-company identification. Journal of Business Ethics, 95(4), 557-569. doi:10.1007/ s10551-010-0440-2

Lambert, E. G. (2010). The relationship of organizational citizenship behavior with job satisfaction, turnover intent, life satisfaction, and burnout among correctional staff. Criminal Justice Studies, 23(4), 361-380. doi:10.1080/1478601X.2010.516533

Leiter, M. P., Bakker, A. B., \& Maslach, C. (2014). The contemporary context of job burnout. In M. P. Leiter, A. B. Bakker, \& C. Maslach (Eds.), Current issues in work and organizational psychology. Burnout at work. A psychological perspective (1st ed., pp. 1-9). London: Psychology Press.

Lin, C.-P., Lyau, N.-M., Tsai, Y.-H., Chen, W.-Y., \& Chin, C.-K. (2010). Modeling corporate citizenship and its relationship with organizational citizenship behaviors. Journal of Business Ethics, 95(3), 357-372.

Maslach, C., \& Jackson, S. E. (1981). The measurement of experienced burnout. Journal of occupational behaviour., 2, 99-113.

Maslach, C., Schaufeli, W. B., \& Leiter, M. P. (2001). Job burnout. Annual Review of Psychology., 52, 397-422.

May, D. R., Gilson, R. L., \& Harter, L. M. (2004). The psychological conditions of meaningfulness, safety and availability and the engagement of the human spirit at work. Journal of Occupational and Organizational Psychology, 77(1), 11-37. doi:10.1348/096317904322915892

Mead, G. H. (1934/1962). Mind, self and society: From the standpoint of a social behaviorist. Chicago: University of Chicago Press.

Melé, D. (2009). Integrating personalism into virtue-based business ethics: The personalist and the common good principles. Journal of Business Ethics, 88(1), 227-244.

Meynhardt, T. (2009). Public value inside: What is public value creation? International Journal of Public Administration, 32(3-4), 192-219.

Meynhardt, T. (2015). Public value: Turning a conceptual framework into a scorecard. In J. M. Bryson, B. C. Crosby, \& L. Bloomberg (Eds.), Public Value and Public Administration (pp. 147-169). Washington, DC: Georgetown University Press.

Meynhardt, T., \& Bartholomes, S. (2011). (De)composing public value: In search of basic dimensions and common ground. International Public Management Journal, 14(3), 284-308. doi:10.1080/10967494.2011.618389

Meynhardt, T., \& Diefenbach, F. E. (2012). What drives entrepreneurial orientation in the public sector? Evidence from Germany's federal labor agency. Journal of Public Administration Research and Theory, 22(4), 761-792. doi:10.1093/jopart/mus013

Meynhardt, T., \& Gomez, P. (2016). Building blocks for alternative four-dimensional pyramids of corporate social responsibilities. Business \& Society. Advance online publication, 1-35. doi: $10.1177 / 0007650316650444$ 
Michaelson, C., Pratt, M. G., Grant, A. M., \& Dunn, C. P. (2014). Meaningful work: Connecting business ethics and organization studies. Journal of Business Ethics, 121(1), 77-90. doi:10.1007/s10551-013-1675-5

Mohr, J., \& Spekman, R. (1994). Characteristics of partnership success: Partnership attributes, communication behavior, and conflict resolution techniques. Strategic Management Journal, 15(2), 135-152.

Mory, L., Wirtz, B. W., \& Göttel, V. (2015). Factors of internal corporate social responsibility and the effect on organizational commitment. The International Journal of Human Resource Management, 27(13), 1393-1425. doi:10.1080/09585192.2015.1072103

Müller, C. von, \& Brieger, S. A. (2016). Public value of environmental investments: A conceptual outlook on the management of normatively determined risks. In V. Ramiah, G. N. Gregoriou (Eds.), Handbook of environmental and sustainable finance (pp. 131-146). Amsterdam: Elsevier.

Nagy, M. S. (2002). Using a single-item approach to measure facet job satisfaction. Journal of Occupational and Organizational Psychology, 75, 77-86.

Newman, A., Nielsen, I., \& Miao, Q. (2015). The impact of employee perceptions of organizational corporate social responsibility practices on job performance and organizational citizenship behavior: Evidence from the Chinese private sector. The International Journal of Human Resource Management, 26(9), 1226-1242. doi:10.1080/09585192.2014.934892

Ng, E., \& Burke, R. J. (2010). Predictor of business students' attitudes toward sustainable business practices. Journal of Business Ethics, 95(4), 603-615.

O'Fallon, M. J., \& Butterfield, K. D. (2005). A review of the empirical ethical decision-making literature: 1996-2003. Journal of Business Ethics, 59(4), 375-413.

Organ, D. W. (1988). Organizational citizenship behavior: The good soldier syndrome. Washington, DC: Heath and Company.

Orlitzky, M., \& Benjamin, J. D. (2001). Corporate social performance and firm risk: A metaanalytic review. Business \& Society, 40(4), 369-396.

Podsakoff, P. M., \& Organ, D. W. (1986). Self-reports in organizational research: Problems and prospects. Journal of Management, 12(4), 531-544.

Podsakoff, P. M., MacKenzie, S. B., Paine, J. B., \& Bachrach, D. G. (2000). Organizational citizenship behaviors: A critical review of the theoretical and empirical literature and suggestions for future research. Journal of Management, 26(3), 513-563.

Podsakoff, P. M., MacKenzie, S. B., Lee, J.-Y., \& Podsakoff, N. P. (2003). Common method biases in behavioral research: A critical review of the literature and recommended remedies. The Journal of applied psychology, 88(5), 879-903. doi:10.1037/0021-9010.88.5.879

Porter, M. E., \& Kramer, M. R. (2011). Creating shared value. Harvard Business Review, 89(1/2), 62-77.

Preacher, K. J., Rucker, D. D., \& Hayes, A. F. (2007). Addressing moderated mediation hypotheses: Theory, methods, and prescriptions. Multivariate Behavioral Research, 42(1), 185-227. doi:10.1080/00273170701341316

Public Value Atlas Switzerland. (2015). Retrieved from www.gemeinwohl.ch/en

Redfern, K., \& Crawford, J. (2004). An empirical investigation of the ethics position questionnaire in the People's Republic of China. Journal of Business Ethics, 50(3), 199-210.

Roeck, K. de, Marique, G., Stinglhamber, F., \& Swaen, V. (2014). Understanding employees' responses to corporate social responsibility: Mediating roles of overall justice and organisational identification. The International Journal of Human Resource Management, 25(1), 91-112. doi:10.1080/09585192.2013.781528

Rosso, B. D., Dekas, K. H., \& Wrzesniewski, A. (2010). On the meaning of work: A theoretical integration and review. Research in Organizational Behavior, 30, 91-127. doi:10.1016/j. riob.2010.09.001 
Saks, A. M., \& Gruman, J. A. (2014). What do we really know about employee engagement? Human Resource Development Quarterly, 25(2), 155-182. doi:10.1002/hrdq.21187

Sardžoska, E. G., \& Tang, T. L. P (2009). Testing a model of behavioral intentions in the republic of Macedonia: Differences between the private and the public sectors. Journal of Business Ethics, 87(4), 495-517.

Schaltegger, S., \& Hörisch, J. (2015). In search of the dominant rationale in sustainability management: Legitimacy- or profit-seeking? Journal of Business Ethics. Advance online publication. https://doi.org/10.1007/s10551-015-2854-3

Schaufeli, W. B., \& Bakker, A. B. (2004a). Job demands, job resources, and their relationship with burnout and engagement: A multi-sample study. Journal of Organizational Behavior., 25, 293-315.

Schaufeli, W. B., \& Bakker, A. B. (2004b). UWES: Utrecht work engagement scale. Preliminary manual. [PDF file]. Retrieved from http://www.wilmarschaufeli.nl/publications/Schaufeli/ Test\%20Manuals/Test_manual_UWES_English.pdf

Schaufeli, W. B., \& Bakker, A. B. (2010). Defining and measurement of work engagement. In A. B. Bakker \& M. P. Leiter (Eds.), Work engagement: A handbook of essential theory and research (pp. 10-23). New York, NY: Psychology Press.

Schaufeli, W. B., \& Salanova, M. (2011). Work engagement: On how to better catch a slippery concept. European Journal of Work and Organizational Psychology, 20(1), 39-46. doi:10.1 080/1359432X.2010.515981

Schaufeli, W. B., Salanova, M., González-Romá, V., \& Bakker, A. B. (2002). The measurement of engagement and burnout: A two sample confirmatory factor analytic approach. Journal of Happiness Studies, 3(1), 71-92. doi:10.1023/A:1015630930326

Schwartz, S. H., \& Bardi, A. (2001). Value hierarchies across cultures: Taking a similarities perspective. Journal of Cross-Cultural Psychology, 32(3), 268-290.

Schwartz, M. S., \& Carroll, A. B. (2008). Integrating and unifying competing and complementary frameworks: The search for a common core in the business and society field. Business \& Society, 47(2), 148-186. doi:10.1177/0007650306297942

Shafer, W. E., Fukukawa, K., \& Lee, G. M. (2007). Values and the perceived importance of ethics and social responsibility: The U.S. versus China. Journal of Business Ethics, 70(3), 265-284.

Siegall, M., \& McDonald, T. (2004). Person-organization value congruence, burnout and diversion of resources. Personnel Review, 33(3), 291-301. doi:10.1108/00483480410528832

Simmons, R. S., Shafer, W. E., \& Snell, R. S. (2013). Effects of a business ethics elective on hong kong undergraduates' attitudes toward corporate ethics and social responsibility. Business \& Society, 52(4), 558-591. doi:10.1177/0007650309350282

Singhapakdi, A., Vitell, S. J., Rallapalli, K. C., \& Kraft, K. L. (1996). The perceived role of ethics and social responsibility: A scale development. Journal of Business Ethics, 15, 1131-1140.

Sison, A. J. G., \& Fontrodona, J. (2013). Participating in the common good of the firm. Journal of Business Ethics, 113(4), 611-625. doi:10.1007/s10551-013-1684-4

Staufenbiel, T., \& Hartz, C. (2000). Organizational citizenship behavior: Entwicklung und erste Validierung eines Meßinstruments. Diagnostica, 46(2), 73-83.

Stryker, S., \& Burke, P. J. (2000). The past, present, and future of an identity theory. Social Psychology Quarterly, 63(4), 284-297.

Tait, M., Padgett, M. Y., \& Baldwin, T. T. (1989). Job and life satisfaction: A reevaluation of the strength of the relationship and gender effects as a function of the date of the study. Journal of Applied Psychology, 74(3), 502-507.

Valentine, S., \& Fleischman, G. (2008). Professional ethical standards, corporate social responsibility, and the perceived role of ethics and social responsibility. Journal of Business Ethics, 82(3), 657-666. doi:10.1007/s10551-007-9584-0 
Vitell, S. J., \& Paolillo, J. G. P. (2004). A cross-cultural study of the antecedents of the perceived role of ethics and social responsibility. Business Ethics: A European Review, 13(2-3), 185-199. doi:10.1111/j.1467-8608.2004.00362.x

Vitell, S. J., Paolillo, J. G. P., \& Thomas, J. L. (2003). The perceived role of ethics and social responsibility: A study of marketing professionals. Business Ethics Quarterly, 13(1), 63-86.

Vlachos, P. A., Panagopoulos, N. G., \& Rapp, A. A. (2013). Feeling good by doing good: Employee CSR-induced attributions, job satisfaction, and the role of charismatic leadership. Journal of Business Ethics, 118(3), 577-588. doi:10.1007/s10551-012-1590-1

Wanous, J. P., Reichers, A. E., \& Hudy, M. J. (1997). Overall job satisfaction: How good are single-item measures? Journal of Applied Psychology, 82(2), 247-252.

Welzel, C. (2013). Freedom rising: Human empowerment and the quest for emancipation. New York, NY: Cambridge University Press.

West, B., Hillenbrand, C., \& Money, K. (2015). Building employee relationships through Corporate Social Responsibility: The moderating role of social cynicism and reward for application. Group \& Organization Management, 40(3), 295-322. doi:10.1177/1059601114560062

Woods, S. A., \& Sofat, J. A. (2013). Personality and engagement at work: The mediating role of psychological meaningfulness. Journal of Applied Social Psychology, 43(11), 2203-2210. doi:10.1111/jasp.12171

Wright, T. A., \& Cropanzano, R. (2000). Psychological well-being and job satisfaction as predictors of job performance. Journal of Occupational Health Psychology, 5(1), 84-94.

Yang, C. (2014). Does ethical leadership lead to happy workers? A study on the impact of ethical leadership, subjective well-being, and life happiness in the chinese culture. Journal of Business Ethics, 123(3), 513-525. doi:10.1007/s10551-013-1852-6 